\title{
Awkward ethnography: an untapped resource in organizational studies
}

Beate Sløk-Andersen and Alma Persson

The self-archived postprint version of this journal article is available at Linköping University Institutional Repository (DiVA):

http://urn.kb.se/resolve?urn=urn:nbn:se:liu:diva-171905

N.B.: When citing this work, cite the original publication.

Sløk-Andersen, B., Persson, A., (2020), Awkward ethnography: an untapped resource in organizational studies, Journal of Organizational Ethnography. https://doi.org/10.1108/JOE-092020-0036

Original publication available at:

https://doi.org/10.1108/JOE-09-2020-0036

Copyright: Emerald

http://www.emeraldinsight.com/ 


\title{
Awkward Ethnography: An Untapped Resource in Organizational Studies
}

\author{
Beate Sløk-Andersen, Postdoc at Department of Organization, Copenhagen Business School, Denmark.
}

Alma Persson, Senior Lecturer at Department of Thematic Studies, Linköping University, Sweden.

Purpose - This article explores the analytical gains of what we refer to as 'awkward ethnography'. How might our understanding of organizational phenomena benefit from those unexpected moments when our observations are laughed at, when our questions cause discomfort, or when we feel like a failure? While such instances seem to be an inherent aspect of organizational ethnography, they are often silenced or camouflaged by claims of intentionality. This article takes the opposite approach, arguing for the analytical value of awkwardness.

Design/methodology/approach - We draw on our respective ethnographic fieldwork in the Danish and Swedish armed forces. Based on observations, participation, and interviews in two military units, the analysis focuses on situations that rarely find their way into final research publications. These will be explored as analytically productive material that can provide crucial insights into the organizational context studied.

Findings - Our analysis demonstrates that awkward situations that arise during ethnographic work not only bring about unforeseen insights; they also enable vital analytical opportunities for discovering silent knowledge in the organization which researchers might otherwise not have considered to inquire about or understood the gravity of.

Research limitations/implications - Implied in the suggested methodological approach for ethnographers is an acceptance of awkward situations as productive encounters. This means doing away with ideals for (ethnographic) knowledge production steered by notions of objectivity, instead embracing the affective dimensions of fieldwork.

Originality/value - This research addresses a key, and often silenced, aspect of ethnographic fieldwork, and stresses the unique value of the unintended and unexpected when doing ethnography.

Keywords - Organizations, ethnography, fieldwork, methodology, affect, analytical process, awkwardness, failure 


\section{Introduction}

It is my first day of fieldwork, following a military unit as they prepare for international service. The first two hours were easy enough; sitting in on a lecture, listening, and taking notes. After the lecture there is a break, and the soldiers gather in groups. They all look almost identical to me, dressed as they are in green camouflage uniforms, while I stand out as the only one in civilian clothes. I am standing outside the classroom, trying to decide where and how to start a conversation. I take a deep breath, put on a smile, and approach one of the groups of soldiers. Instantly, they all fall silent and a few seconds later they begin to stir. Soon the group is dissolved, and I am the only one left. As I work on my field notes and reflect on the situation later that night, I write: "I feel like an alien. The soldiers won't even talk to me. How am I supposed to get through this?"

As organizational ethnographers, we have often found ourselves in situations that feel awkward. In our attempts to gain insight into various organizational phenomena - in our case, gender relations in the armed forces - we need to embark on journeys that take us into unknown territory. This is an endeavor that can bring with it both embarrassment and nervousness as our observations are sometimes laughed at, our questions create confusion, or our mere presence causes unease. We might sense this through an all too long a silence, a crude remark, the fidgeting with papers, or perhaps a look of confusion that leaves us with a feeling of failure. And while such instances might be considered inherent to ethnographic fieldwork, they are often silenced or camouflaged by claims of intentionality. In this article, we take the opposite approach, arguing for the analytical gains of what we refer to as awkward ethnography.

Scholars across the social sciences and humanities have long debated if and how impartial and objective research can be made possible, implying a concept of uncontaminated, value neutral or bias-free research as the ideal (Becker, 1967; Bernstein, 1983; Harding, 1986; Haraway, 1988). For scholars doing ethnographic fieldwork, such ambitions of objectivity can appear farfetched or even illusionary (see e.g. Skeggs, 1994). Rather than contributing to the difficult and perhaps unfruitful question of how to do research as objectively or impartially as possible, we want to explore what we might achieve if we, as organizational ethnographers, embrace the entailed affects of doing ethnographic work. Inspired by the recent work of Ahmed (2014a; 2014b; 2014c) and Stewart (2007), we attend to awkwardness as affective shifts that open up to analytical insights about unspoken assumptions and silenced knowledge in organizational settings; matters that researchers might otherwise not have considered to inquire about or understood the gravity of.

For this purpose, we use our respective experiences of doing fieldwork in the Danish and the Swedish armed forces; an empirical field that highlights the still-relevant question posed by Becker in 1967: "Whose side are we on?" Within the anthropological tradition, for instance, engaging with military issues or even collaborating with military organizations has been - and still is - the root of many heated debates (Lucas, 2009; McNamara and Rubinstein, 2011; Rubinstein et al., 2013). The field simply urge us to take sides. This is also very much the case for scholars such as ourselves, approaching the subject matter from a feminist-inspired standpoint. Due to close historic ties between peace movements and feminist scholarship, a strong and explicit antimilitaristic positioning is not uncommon, one example being Enloe (2007, p. 93) who has stated that people arguing for the enlistment of more women in state militaries "have a stake in perpetuating a patriarchal culture and structure". Rather than responding to the sneaking sense of both shame and pride that such claims can leave us with, we want to embrace the affective dimensions of our work that these debates on positionality tinker towards, following the claim that affect punctuates "matter into what matters" (Kuhn et al., 2017: 60). 
We argue that those intense sensations of discomfort we experience as ethnographers - due to calls for taking sides, being outsiders in the field, or something completely different - might actually point us towards crucial analytical insights. We will therefore explore the methodological opportunities that lie beside and beyond the questions of taking sides as either/or and for-or-against. And while the cross field between anthropology and militaries might make up a particularly morally contested field (Sørensen and Weisdorf, 2019), we want to utilize this empirical field as an entryway to grasping the usefulness of affects in organizational ethnography at large. ${ }^{1}$ While affects have too often been overlooked by ethnographers - not least when these sensations do not sit well with us or our sense of professionalism - we want to unfold their methodological potential. Joining other scholars who have recently made up for this neglect in studies of organizational phenomena (Jemielniak and Kostera, 2010; Koning and Ooi, 2013; Tracy, 2014), we will explore how the affective dimensions of ethnography can be considered an untapped resource when studying organizational phenomena - in military settings as well as any other organizational field.

\section{Affect as theory and methodology}

Affects are phenomena that we often find difficult to describe; a sensory feeling that we might feel unable to put into words. Trying to encapsulate the meaning and analytical potential of these phenomena, scholars of affect theory such as Massumi (2002) define affect as the "capacity to affect and be affected" (p. 5). Applying a more critical perspective than Massumi, scholars such as Ahmed (2014a; 2014b; 2014c) and Stewart (2007) are taking the field further, connecting the concept of affect to societal and political matters; it is this conceptualization we will rely on.

Central for these scholars is a focus on that which is 'outside' language - a desire to grasp bodily sensations, encounters, forces, and momentum. Affect is about the intensity of meaning; how it materializes and moves. Affect "passes, travels, circulates, and connects across time and space" (Gherardi, 2019, p. 748, see also Bjerg and Staunæs, 2011) and thus comes into existence by the relations and materiality of a certain context. While the concept of emotions through the 1970s and 1980s was applied to show "how feelings variously fix and stick through different compositions of language and discourse", affect is employed to "show how some feelings slip, evade, and overflow capture." (White, 2017, p. 175) It is exactly this slippery nature of affect that we would argue carries important analytical potential; the potential for addressing the sensations that may impact not only the individual (the ethnographer) but also the collective (informants, the field), without really being recognized or articulated in the situation. While emotions have often been perceived as something that comes from within; something that you can possess or something that you are ('I am mad'), the concept of affect opens up to a fluidity of feelings that we can use to understand the social interactions ethnographers inevitably are part of.

In Stewart's Ordinary Affects (2007), we find a lead as to how to conceptualize the awkwardness that we have encountered and embodied in our research. Relevant across all disciplines working ethnographically, Stewart argues that it is in the ordinary events and routines of everyday life that we find the mechanisms shaping our being in the world. Specifically, it is the affective dimensions of the ordinary that should be of interest to us as researchers since ordinary affects "give everyday life the quality of a continual motion of relations, scenes, contingencies, and emergencies." (ibid., p. 2) Through their capacity to affect - of creating effect and movement - ordinary affects make 'something' come together as bodies are activated through flows of affect.

Stewart uses the term attunement to describe the sense of being "at attention" that comes with this 'something.' In a military setting, being at attention means being alert and ready to take orders - a sort of disciplined anticipation. However, for Stewart, this describes an affective shift that changes a scene. These shifts can easily be overlooked, yet attunement is crucial in the research process as it offers potential modes of knowing; it is a 
process of discovering the "possibilities (and threats) that have come into view" (ibid., p. 5). It is this exact potential that we urge to unbox and utilize, even (or perhaps, especially) when it feels a bit unsettling or embarrassing. As we reflect back on those moments where the scene changed and 'something' happened, how can we create meaning out of these affective experiences?

In arguing for the relevance of affect in organizational studies, we are far from its first proponents. Indeed, under the headline "Thinking critically about affect in organization studies: why it matters", Fotaki et al. (2017) have argued for the relevance of thinking through affect when trying to understand organizations (see also Kenny et al., 2011). Recent examples of scholars doing exactly that are Kantola et al. (2019) who have unpacked how top executives navigate affectively through market liberalization, and Pouthier and Sondak (2019) who have explored connections between bodily norms and affect in organizations. However, as in the work of Ahmed, affect ends up being the object of the study and not a methodological approach that can be used to study the object with.

This is amended by scholars working with affective methodologies (Staunæs and Kofoed, 2015; Knudsen and Stage, 2015; Staunæs 2016). Of particular relevance to our own endeavor, Gherardi (2019) has introduced the concept of affective ethnography to conceptualize how affect is inherently entangled in the practices of ethnographers exploring organizations (as well as any other social setting) ${ }^{[2]}$ Gherardi uses the term to refer to "a style of being in the field, being with and becoming-with others" (ibid., p. 742), thus adding to the work of scholars before her who have attempted to do away with research as representation (Law, 2004; Barad, 2007; Haraway, 2008). Focusing specifically on ethnographic work, Gherardi encourages us to embrace affect as a resource, suggesting that we ask "“what affect does' to us in ethnographic practices and [...] what we can do with our embodied capacity to affect and be affected." (ibid., p. 744).

Indeed, doing ethnographic work has consequences for those embodying the experience; the exhaustion, the embarrassment, the confusion, the fear, the humiliation, the pride, the joy, the thrill. An extremely vivid example is Warden's (2013) account of how conducting research in a setting characterized by violence and insecurity consequently lead to a post-traumatic stress disorder (PTSD) on the researcher's part; something Warden uses to illustrate how the "emotional struggles of the researcher are seldom examined in detail" (ibid., p. 151). The socio-material setting that we may refer to as 'the field' affects us. The question is how to make analytical use of these affective encounters, if we accept the premise that "affect makes a difference." (Kuhn et al., 2017, p. 60). For this purpose, we need to consider our ethnographic approach through a lens of affect.

\section{An ethnographic approach to awkwardness}

Through stories from peers, students, and old ethnographies, we get a sense of awkwardness as quite unavoidable when doing ethnographic work. Our own experiences with awkwardness are diverse and recurrent. We build on Gherardi's concept of affective ethnography as we explore the methodological implications and analytical potential of the seemingly negative and unprofessional affects we experience in fieldwork. Specifically, our aim is to illuminate what we 'can do' with embodied experiences of awkwardness when the object of the study is an organization. We are not claiming that we are encapsulating comprehensively the affective dimensions of doing organizational ethnography, but, inspired by Stewart, presenting glimpses and scenarios of awkwardness that have stuck with us and have become crucial analytical insights because 'something' happened.

Turning briefly to more formal definitions of being awkward, we are offered a wide range of ways to describe this unsettling sensation. The Cambridge Dictionary (2019) lists a range of definitions that ooze affect and illuminate the bodily sensation as we read definitions such as: "difficult to use, do, or deal with"; "causing problems, worry, or embarrassment"; "intentionally not helpful"; "moving in a way that is not natural, relaxed, or attractive": and "causing inconvenience, anxiety, or embarrassment". These are descriptions that few would 
hope to be associated with within a professional context: "intentionally not helpful" or "difficult to deal with" hardly being desired characteristics in a neoliberal academic setting (Ashcraft, 2017). ${ }^{[3]}$ Oftentimes, awkwardness feels like the outcome of us, the ethnographers, messing things up and "causing problems". Indeed, the feeling of failure is something that researchers often experience in fieldwork. Jemielniak and Kostera (2010) analyze accounts that organizational ethnographers describe as instances of failure in their fieldwork. They argue, as do we, that research failures are undertheorized as a methodological issue in studies of organizations. In their analysis, they argue that the otherness of organizational ethnographers is key to successful research, close to the traditional ethnographic ideal that one should not study one's own culture (ibid.).

This ties to the question of learning: before silent knowledge, norms, and routines of the organization "sink into the body and turn into reflexes" (Ehn et al., 2015: 6), awkward and unintended situations are both recurrent and inevitable. This way, ethnographers bear a great resemblance to newcomers in general, as also argued by Spradley (1980). We tend to learn much through the process of not understanding what is going on and not having access to common assumptions in organizations; something that was developed methodologically by Garfinkel (1967). And while much awkwardness emerges from scholars being newcomers to the organization, it might also be the outcome of our mere presence or unexpected situations where our gender, age, allergies, beliefs, arguments, or ideas causes ruptures, questions, confusion, or awkward laughter (Star, 1990; Ahmed, 2017). In other cases, the mood would have been awkward regardless of our saying and doing.

Regardless of the scenario that brought it about, awkwardness tends to disappear in the process of turning observations, shadowing, participation, and conversations into 'findings.' Perhaps we do not make a record of, or even fully make sense of, these moments where 'something' happens and the situation suddenly becomes awkward. Who wants to be reminded of all that went wrong, or at least felt as if it went wrong? To make amends for our own complicity in this, we will in the following section air some of our own 'dirty laundry' to demonstrate how the feeling of having messed up can actually lead to unique insights. In doing so, we hope to challenge the tendency of seeing these moments of awkwardness as dirty laundry in the first place. The examples included and unfolded in this paper are from our respective ethnographic endeavors within the armed forces of Sweden and Denmark. Before turning to the analysis, we will provide a short introduction to the two case studies.

\section{The Danish case}

Sløk-Andersen: Curious to explore the values and norms established at entry-point in the military profession, my ethnographic work has circled around conscription; a century-old system of compulsory military training for all male citizens still in place in Denmark. After having initially observed the draft examinations where young citizens' eligibility for military service is evaluated, I moved on to experience military training on and through my own body. Deciding to engage my own body more extensively in this part of the study came about due to narratives about the very physical nature of military work (Lande, 2007; McSorley, 2015); something I wanted to gain insight into by "performing the phenomenon" (Wacquant, 2006) myself. To make sure that my own experience of going through basic training was levelled out by that of others, I also conducted 39 qualitative interviews with soldiers who were responsible for or going through the basic training.

\section{The Swedish case}

Persson: My study targeted the issue of how gender relations in the Swedish Armed Forces were re-shaped, as the focus of the military organization transformed from defending the nation's borders from armed attack to taking part in international operations. When designing the ethnographic case study of a military unit 
undergoing the final stages of training before deployment abroad, I had previously conducted two separate case studies based primarily on qualitative interviews. The fieldwork took place over the course of five weeks, which I spent with the military unit as the soldiers practiced at the shooting range, sat through lectures, or practiced riot control with Molotov cocktails flying over their heads. Whenever possible, I conducted informal interviews in addition to conducting observations. The central themes explored during fieldwork were gender relations, divisions of labour, professional norms, and soldier subjectivites.

\section{Analysis: Awkward encounters in the military field}

Over the course of our respective ethnographic endeavors, we both experienced several awkward moments. As the scenario opening this article illustrated, they may already appear on the first day of fieldwork - and reappear all the way through the ethnographic process. For one of the authors, being asked if she wanted to do coke with some of the soldiers marked the awkward end to a fieldwork with daily interaction, joking, and caring for each other. The awkwardness of the situation did not arise from the unexpected offer to do coke per se, but rather the prompt "No!" exclaimed by another soldiers as he heard the offer being extended to the adult/woman/researcher/observer/outsider. Indeed, our "ambiguous positioning" in a morally contested field can in itself cause a sensation of awkwardness, as noted by Sørensen and Weisdorf (2019, p. 10). But we want to broaden the scope and think through a broad array of moments where awkwardness arose not just from matters of positionality but simply from doing research that "requires close (as possible) encounters with the subjects and objects of our research." (Brannan et al., 2012, p. 8) In line with the affective approach introduced above, such encounters entail that we allow ourselves to become part of the affective flows of the organization.

Through short vignettes we will introduce concrete examples of awkwardness from our ethnographic work. Like the case introductions above, these vignettes will be presented from a first-person perspective by the author who embodied this specific situation, followed by a collective reflection and discussion of these examples.

\section{Vignette 1: Peacebuilding and the making of soldiers}

Towards the end of my participatory fieldwork in an army platoon, I had set up an interview with our company commander, also known as "The Boss" as he was in charge of both officers, sergeants, and recruits. Due to his busy schedule, it had been a bit difficult to make the interview happen. When we finally sat down in his office, he seemed a bit annoyed or just in a hurry, which made me try to go through the prepared questions quicker than I normally would. Having researched the development of the military profession before initiating this fieldwork, one of my questions was about the apparent lack of training in peacekeeping related tasks, as all of our drills had been more or less focused on us learning to shoot down the enemy. As he looked puzzled by my question, I tried reframing it, specifically mentioning 'the humanitarian turn' that I had read about. His look of confusion turned into a look of insult or annoyance.

He seemed disappointed that I had not 'gotten it' yet, that is, the correct perception of the military profession. Having been in his custody for almost four months, I felt embarrassed to ask a question that was received so poorly. The sensation in the room was truly awkward. I fidgeted in my chair as I waited for him to correct me, which he eventually did. He explained to me how he did "not see soldiers as humanitarian workers," referring to the necessity of their use of force and weapons. To accommodate my inquiry, he added that a task for soldiers could also be "to stand with our weapon on our back and just be present" but that additional training 
in this type of tasks is easy to add later. "Basically, we are making soldiers. Everything else has to wait."

An attention to combat in a military context is hardly surprising. Indeed, drills primarily focused on shooting down the enemy, the annulment of "Deployment to peacekeeping missions" as a topic included in military basic training, and international humanitarian law being introduced as "the most dull thing you will encounter" had already indicated an emphasis on combat and a use of weapons. But in this instance with "The Boss," the gravity of this backdrop and the implied disconnect between political, scholarly analyses and organizational practices became vivid through the fidgeting and the silence. The affective shift during the interview situation - what Stewart refers to as attunement - made 'something' come together, namely a valuably analytical insight.

The sense of unease and awkwardness that arose in this situation is stored as a quite vivid bodily memory for the author behind this study. But analytically, it opened up to an important realization about the military profession and the basic training newcomers receive, namely, that while scholarship and international policy has emphasized a turn towards more peacekeeping and dialogue-based work (Sion, 2004; Kronsell, 2012; Egnell et al, 2014), a more active use of force continues to be seen as the core of the profession (see also Persson, 2011). "Making soldiers" is not about teaching them to ensure peace but rather teaching them to enact violence. This realization revealed a pattern of how the military profession through military service - which works as the primary recruitment platform for the entire armed forces in both Sweden and Denmark - was showcased in ways that attracted recruits by the possibility of becoming 'real soldiers' through "tests and trials of extreme bodily experiences in warzone deployment, including, above all, real combat" (Pedersen, 2017, p. 205). In reality, however, 'real combat' is something only few Danish and Swedish soldiers experience, even when deployed. Furthermore, the situation in the vignette revealed an understanding of the organization's orientation towards combat as the backdrop of (ideally) everything that the organization does; something that is specific to time and place as the country in question quite recently has turned into a "warring nation" (Daugbjerg and Sørensen, 2017).

What we both have experienced in our ethnographic work is how there are questions that cannot be asked because they are outside the social realm of the organization that we are studying. Bringing up peacekeeping as an inherent element of military work was an example of such a question, which consequently was met with a lack of understanding and annoyance. Such experiences echo the work of Cohn (1987), who has illustrated how the language on nuclear warfare used amongst defense intellectuals in the US was shaped by how they did (not) think about the subject matter. A poignant example is how "human death", through a specifically adapted language, is transformed into the removed term "collateral damage," thus creating distance from "the graphic reality behind the words" (ibid., p. 690). This 'removal' of certain words and topics means that some questions are considered illegitimate; disturbing, irrelevant, improper, unprofessional. They are, we might say, avoided in an attempt to steer clear of certain affective flows. Asking about these deliberately avoided affects, the following vignette also holds an example of an 'illegitimate' question causing an awkward situation.

\section{Vignette 2: "That sounds like rape in the shower, sort of"}

On Tuesday I was having lunch with the soldiers, as always, but it was not just any lunch. The evening before, I had observed the soldiers as they underwent the dreaded pepper spray exercise, which is a requirement for those who intend to carry and use this weapon themselves. The soldiers were tired, and their eyes still red from the pepper spray. The night before they had stood in the shower fully dressed in their uniforms, pouring water into their eyes to try to stop the burning sensation. Some of them cried for their mother, while others were held by their partners in an attempt to ease the panic and soothe the pain. Witnessing it all was an intense experience. 
At lunch the day after, it was apparent that the soldiers were still affected by the experience - and so was I. They were comparing their experiences, sharing war stories in the making. Some seemed proud, others embarrassed. Commenting on the events of the night before, one soldier said with a crooked, ironic smile: "Things were damn manly in the shower, huh?" "Yeah," another replied, "there we were, holding each other and stuff." As I was still taken by the intimacy and comradery I had witnessed, I entered the conversation. "Yes," I said, "but that was really nice, wasn't it? There was a lot of love there." The guys stir, seemingly uncomfortable. After an awkward silence, one responded: "That sounds like rape in the shower, sort of." "Yeah," another soldier adds, "grabbing each other's ass and stuff."

This vignette sheds light on a very concrete example of the failures in fieldwork that Jemielniak and Kostera (2010) wrote about, as the researcher's lack of understanding of soldier jargon becomes obvious - to say the least. Supporting their claim, the situation that the organizational ethnographer encountered did indeed open up to crucial insights. This vignette also reveals an awkwardness on the part of the soldiers, who could not quite come to terms with what happened in the shower the night before. It seems apparent that the soldiers somehow needed to distance themselves from the intimate, emotional and caring aspects of it all. "Holding each other and stuff" appears to be a source of embarrassment that was difficult to integrate with their perceptions of what it means to be "manly". From this spontaneous remark that was spurred by the researcher beginning to feel 'settled in' came material that turned out to be crucial for the analysis. On one hand, since this was not intentional, it could be considered just another case of an ethnographer putting their foot in their mouth during fieldwork. In this case though, it also turned out to be a key to unlocking a very important aspect of the analytical process. Indeed, there had been other cases where sexist and homophobic remarks had been made ("Fucking fag!"), or when soldiers had staged performances, jokingly drawing on homoeroticism, to amuse their peers. In a conversation with a commanding officer describing comradery as the very essence of military work, he praised his deputy by saying that "we would do anything for each other" - and then quickly adding "but nothing sexual, that's where we draw the line". The tension and friction surrounding homosexuality was present throughout the fieldwork, in more or less subtle form. The pepper spray discussion, and especially the foot-in-mouth comment made by the researcher, worked as a spotlight that instantly illuminated the intricate balancing act between intimacy and heterosexuality that the soldiers were engaging in. In this case, awkwardness functioned as a catalyst that brought together and helped make sense of the myriad of ethnographic accounts where masculinity, intimacy and comradery were somehow at stake.

The lunch conversation opened up a following analysis of the military brotherhood, where intimacy and camaraderie was taken as one of the reasons they wanted to join and stay in the military (Persson, 2012). Why, then, were the soldiers so determined to steer clear of this camaraderie being associated with love or sex? One conclusion was that the "band of brothers" was so important to the soldiers because it allowed them to form strong and intimate bonds of friendship beyond what was available to them in their civilian lives. But comments such as "rape in the shower" show that they could only do so within a setting that remained undoubtedly heteronormative. The constant affirmation of heterosexuality formed the "scene of constraint" (Butler, 2004, p. 1) within which soldiers constructed a highly traditional, stereotypical version of being military men. If heterosexuality did not frame their closeness, the soldiers would find themselves in a completely different terrain, which is why the comment about love, read by the soldiers as a reference to homosexuality, really touched a nerve.

As especially this second vignette illustrates, Gherardi's term of affective ethnography as "the researcher's capacity to affect and be affected" proved very accurate, not least as it helped "produce interpretations that may transform the things that they interpret" (2019, p. 742). Just as the field affects us, we affect the field. Our questions or bodily presence might cause an affective attunement that calls everyone "at attention" because 
'something' happens. Such shifts might not have stayed with the commander from the first vignette or the soldiers from the second vignette because such shifts of scene are easily overlooked. But as ethnographers, we should be aware of the "possibilities (and threats) that have come into view" (Stewart, 2007, p. 5) as these shifts occur. Just look at the analytical potential they carried in our two cases, hiding beneath an intense sense of awkwardness and failure.

However, we also need to acknowledge the more troublesome dimensions that might be entangled in those awkward encounters. This became vivid as one of us, standing with a commander in front of two male soldiers during a fieldwork at a military camp, was asked to take her pick as to who she wanted to ride along with to the shooting range. "They're equally hot, right?" the commander added, leaving the author at a loss for words. Besides making an adult professional feel like a blushing schoolgirl, this moment also highlighted the issue of sexual harassment as a recurring phenomenon in military organizations (Firestone and Harris, 2003; Øhrstrøm, et al., 2003; MacKenzie et al., 2020). And while 'awkward' was the only instinctive way for the ethnographer to describe this situation, it brought together assumptions about sexuality and power relations that disrupted ambitions on the researcher's part to "do no harm" (AAA Ethics Forum 2019). Since awkwardness rarely stands alone - but rather entangles with dimensions such as power, norms, and recognition - we should be aware of how awkwardness might also point towards ethical issues in our material. By focusing on awkwardness in this analysis, we are not encouraging fellow organizational ethnographers to disregard other entangled matters, but rather to use awkwardness as a methodological spotlight that can highlight silenced knowledge and unspoken norms in our field.

\section{Discussion: Placing awkwardness front and center}

Throughout this article, we have argued that awkward encounters in ethnographic work can be of great methodological value when studying organizational phenomena. However, taking the matter one step further, we want to suggest a focus on ethnography as awkward encounters. Rather than framing these experiences as exceptions, failures, or something we hide in the margins of our field notes (or leave out entirely), we argue that they should be placed front and center. Instead of weeding out the awkwardness, because it does not fit the scholarly narrative we are trying to produce, we should make them our starting point for analysis. Those awkward moments when we feel like we have completely messed up might not always prove central to the analysis, but as we have shown they often carry vital analytical opportunities for discovering silent knowledge and assumptions taken for granted in the organization.

With the opening scene, where one of us felt like an alien as the soldiers around fell silent and eventually scattered, we wanted to convey an experience that would be familiar to most scholars working ethnographically. It will most likely be relatable across empirical fields. While being an almost generic example, however, the awkwardness in this situation flagged numerous valuable analytical insights particular to the military context. Sticking out visually as the only one not wearing a uniform, for instance, became an embodied experience of what many civilians working in the military describe (Persson, 2010). Further, being the only woman present opened up to how the male gender has been incorporated as an invisible and assumed neutral standard within the military profession (Sløk-Andersen, 2019); something that was highlighted by being referred to as "the lady" numerous times thereafter. But as the awkwardness floods us, we have little chance of grasping these analytical openings in the heat of the moment. Awkwardness is the exact reason why we do not interfere or try to handle the situation; it is a sort of paralyzing force that prevents us from taking action and turns us into passive observers, if only for a moment. Just like the rest of the empirical examples presented in this article, the sense of awkwardness sat with us long after exactly because we did not repair, make sense, or fully deal with the situation, in the situation. Consequently, it lingered on in our embodied 
memories of the field. Moving towards a greater methodological mobilization and exploration of the affective dimensions of ethnographic work therefore entails a greater recognition of "how feelings slip, evade, and overflow capture." (White 2017, p. 175)

Trying to understand why this methodological value of awkwardness is rarely utilized, our attention turns to an aspired scholarly professionalism and notions of objectivity. Despite the fact that "You have to be willing to look like an idiot-like a horse's ass - to do fieldwork" (Tracy, 2014: 458), this aspect of our line of work is rarely addressed. Perhaps this is because failure and insecurity does not sit well with "the intellectual mission of ethnographers [which] has always been to 'render the actual - and to do so persuasively"' as Smets et al. (2014, p. 11) have noted, drawing on Van Maanen (2011). Fleshing out those encounters that felt like failures after a careful process of gathering empirical material can seem at odds with the ambition of rendering the actual "persuasively".

As scholars trained in an ethnographic tradition and strongly influenced by feminist methodology, our understanding of knowledge production has to a large degree been shaped by a critique against neutrality, objectivity, and an 'uncontaminated' empirical material as the ideal (Harding, 1986; Haraway, 1988). We see our own research practices as situated knowledges (Haraway, 1988), our perspectives as partial, and ourselves as very much a part of the process of knowledge production. Nonetheless, it has proven difficult for us to fully discard traditional ideals of 'proper' science and ethnography. The examples raised in this article - where we have blushed, felt embarrassed, and made others feel uneasy - have left us with a sense of not being a proper scholar (professional, rational, unbiased). Advocating for an inclusion of awkwardness in the ethnographic process, we hope to challenge ideals for (ethnographic) knowledge production steered by those notions of objectivity and intentionality apparently still haunting us.

We need to fight the ghosts of ethnographies past; something that can be done by recognizing the affective dimensions of doing ethnographic work. Supporting the relevance of this suggestion, calls or urges for taking sides in ethnography indicate exactly such affective dimensions; just think of the heated debates initiated as Becker (1967) urged us to consider "Whose side are we on?" (see also Hammersley, 2001). While the question is as relevant and important as ever, we want move beside and beyond the debate on positionality as either/or and for-or-against and instead explore the affective flows they help make visible. By recognizing and analytically engaging with those intense sensations of discomfort we experience as ethnographers - as they emerge from calls for taking sides, being outsiders, or something else - we can start to explore the potential of awkward ethnography.

We thus encourage our peers to embrace that which might have been discarded as failures in the ethnographic work and instead consider ethnography as inherently awkward. What might be revealed if we take those awkward situations as exceptionally important encounters in our ethnographic work, and treat them as an untapped analytical resource? In our work, these situations turned out to be invaluable resources for realizing the full potential of our ethnographic material.

\section{Acknowledgements}

We would like to thank the editors of this special issue for giving us the chance to contribute to this exciting discussion and the two anonymous reviewers for giving us valuable input. We would also like to thank Karen L. Ashcraft and Tim Kuhn for giving the first author a thorough introduction to affect theory during the New Materialism seminars at University of Colorado, Boulder. Equally, we want to give thanks to colleagues at 
Tema Genus, Linköping University, who have provided valuable input on an earlier version of this manuscript. We are grateful to Laurice Karkaby for offering her language editing expertise.

The ethnographic work described in this article has been carried out during our respective PhD studies at the University of Copenhagen (Sløk-Andersen) and Linköping University (Persson); both positions funded by the host university. While writing and publishing this article, our work has been funded by NordForsk (grant no. 88041).

\section{References}

AAA Ethics Forum (2019) “The American Anthropological Association's Statement on Ethics", available at http://ethics.americananthro.org/ethics-statement-1-do-no-harm/ (accessed 13 December 2019).

Ahmed, S. (2014a), "Not in the mood", New Formations, Vol. 82, pp. 13-28.

Ahmed, S. (2014b), Willful Subjects, Duke University Press, Durham and London.

Ahmed, S. (2014c), The Cultural Politics of Emotion, $2^{\text {nd }}$ edition, Edinburgh University Press, Edinburgh.

Ahmed, S. (2017), Living a Feminist Life, Duke University Press, Durham and London.

Ashcraft, K. L. (2017), “'Submission' to the rule of excellence: Ordinary affect and precarious resistance in the labor of organization and management studies", Organization, Vol. 24 No. 1, 36-58.

Barad, K. (2007), Meeting the Universe Halfway. Quantum Physics and the Entanglement of Matter and Meaning. Duke University Press, Durham.

Becker, H. S. (1967), “Whose side are we on?”, Social Problems, Vol. 14 No. 3, pp. 239-247.

Bernstein, R. J (1983), Beyond Objectivism and Relativism: Science, Hermeneutics, and Praxis, University of Pennsylvania Press, Philadelphia, PA.

Bjerg H. and Staunæs, D. (2011), "Self-management through shame. Uniting governmentality studies and the 'affective turn'”, Ephemera, Vol. 11 No. 2, 138-156.

Brannan, M., Rowe, M. and Worthington, F. (2012), "Editorial: Time for a new journal, a journal for new times", Journal of Organizational Ethnography, Vol. 1 No. 1, pp. 5-14.

Butler, J. (2004), Undoing Gender. Routledge, New York and London.

Cambridge Dictionary (2019) "Awkward", available at https://dictionary.cambridge.org/dictionary/english/awkward (accessed 12 December 2019).

Cohn, C. (1987), "Sex and Death in the Rational World of Defense Intellectuals", Signs, Vol. 12 No. 4, pp. 687-718.

Daugbjerg, M. and Sørensen, B. R. (2017), “Becoming a warring nation: The Danish 'military moment' and its repercussions", Critical Military Studies, Vol. 3 No. 1, pp. 1-6.

Egnell, R., Hojen, P. and Berts, H. (2014), Gender, Military Effectiveness, and Organizational Change: The Swedish Model. Palgrave Macmillan, London.

Ehn, B., Löfgren, O. and Wilk, R. R. (2015), Exploring Everyday Life: Strategies for Ethnography and Cultural Analysis. Rowman \& Littlefield, London. 
Enloe, C. (2007), Globalization and Militarization. Rowman \& Littlefield Publishers, Lanham, MD.

Felski, R. (2000), Doing Time. Feminist Theory and Postmodern Culture. New York University Press, New York, NY.

Firestone, J. and Harris, R. (2003), 'Perceptions of effectiveness of responses to sexual harassment in the US military, 1988 and 1995', Gender, Work and Organization, Vol 10, pp. 42-64.

Fotaki, M., Kenny, K. and Vachhani, S. J. (2017), "Thinking critically about affect in organization studies: why it matters", Organization, Vol. 24 No. 1, pp. 3-17.

Garfinkel, H. (1967), Studies in Ethnomethodology. Polity Press, Cambridge.

Gherardi, S. (2019), "Theorizing affective ethnography for organization studies", Organization, Vol. 26 No. 6, pp. 741-760.

Hammersley, M. (2001), "Which side was Becker on? Questioning political and epistemological radicalism", Qualitative Research, Vol. 1 No. 1, pp. 91-110.

Haraway, D. (1988), "Situated Knowledges. The Science Question in Feminism and the Privilege of Partial Perspective”, Feminist Studies, Vol. 14 No. 3, pp. 575-99.

Haraway, D. (2008), When Species Meet. University of Minnesota Press, Minneapolis, MN.

Harding, S. (1986), The Science Question in Feminism. Cornell University Press, Ithaca and London.

Jemielniak, D. and M. Kostera (2010), "Narratives of irony and failure in ethnographic work", Canadian Journal of Administrative Sciences, Vol. 27 No. 4, pp. 335-347.

Kantola, A., Seeck, H. and Mannevuo, M. (2019), "Affect in governmentality: top executives managing the affective milieu of market liberalization”, Organization, Vol. 26 No. 6, pp. 761-782.

Kenny, K., Muhr, S. L. and Olaison, L. (2011), “The Effect of Affect: Desire and Politics in Modern Organizations", Ephemera, Vol. 11 No. 3, pp. 235-42.

Knudsen, B. T. and C. Stage (Eds.) (2015), Affective Methodologies: Developing Cultural Research Strategies for the Study of Affect. Palgrave Macmillan, London.

Koning, J. and Ooi, C.-S. (2013), Awkward encounters and ethnography. Qualitative Research in Organizations and Management, Vol. 8 No. 1, pp. 16-32.

Kronsell, A. (2012), Gender, Sex, and the Postnational Defense. Militarism and Peacekeeping. University Press, Oxford.

Kuhn, T., Ashcraft, K. L. and Cooren, F. (2017), The Work of Communication. Relational Perspectives on Working and Organizing in Contemporary Capitalism. Routledge, New York, NY.

Lande, B. (2007), "Breathing like a soldier: culture incarnate", The Sociological Review, Vol. 55 No. 1, pp. 95-108.

Law, J. (2004), After Method: Mess in Social Science Research. Routledge, London.

Lucas Jr., G. R. (2009), Anthropologists in Arms. The Ethics of Military Anthropology. AltaMira Press, New York, NY. 
MacKenzie, M., Gunaydin, E. and Chaudhuri, U. (2020), Illicit military behavior as exceptional and inevitable: Media coverage of military sexual violence and the "bad apples" paradox. International Studies Quarterly, Vol. 64, pp. 45-56.

Massumi, B. (2002), Parables for the Virtual: Movement, Affect, Sensation. Duke University Press, Durham.

McNamara, L. A. and Rubinstein, R. A. (2011), Dangerous Liaisons: Anthropologists and the National Security State. School for Advanced Research, Santa Fe, NM.

McSorley, K. (Ed.) (2015), War and the Body. Militarisation, Practice and Experience. Routledge, New York, NY.

Øhrstrøm, B., Eriksen, J. and Knudsen, L. (2003), Undersøgelse af forekomst af og oplevelse af kønskrankende adfcerd i Forsvaret. Hovedresultater. Forsvarsakademiet, Copenhagen.

Pedersen, T. R. (2017), Soldierly Becomings. A Grunt Ethnography of Denmark's New 'Warrior Generation'. PhD dissertation, Faculty of Social Sciences, University of Copenhagen.

Persson, A. (2010), Soldiers and secretaries: Gendered boundary work in the Swedish Armed Forces. Scandinavian Journal of Management, Vol. 26 No 2, 166-175.

Persson, A. (2011), Changing boundaries, defending boundaries. Gender relations in the Swedish Armed Forces, PhD dissertation, Faculty of Arts and Science, Linköping University.

Persson, A. (2012), An unintended side effect of pepper spray: Gender trouble and "repair work" in an armed forces unit. Men and masculinities, Vol. 15 No. 2, pp. 132-151.

Pouthier, V. and Sondak , H. (2019), "When shame meets love: Affective pathways to freedom from injurious bodily norms in the workplace", Organization Studies, 1-22.

Pullen, A. and Rhodes, C. (2008), "Dirty writing", Culture and Organization, Vol. 14 No. 3, pp. 241-59.

Pullen, A., C. Rhodes and T. Thanem (2017), "Affective politics in gendered organizations: affirmative notes on becoming-woman", Organization, Vol. 24 No. 1, pp. 105-123.

Rubinstein, R. A., Fosher, K., and Fujimura, C. (2013), Practicing Military Anthropology. Beyond Expectation and Traditional Boundaries. Kumarin Press, Sterling, VA.

Sion, L. (2004), Changing From Green to Blue Beret: a Tale of Two Dutch Peacekeeping Units, PhD dissertation, Amsterdam Institute for Social Science Research, Free University of Amsterdam.

Skeggs, B. (1994), "Situating the production of feminist ethnography", in Maynard, M. and Purvis, J. (Eds.), Researching Women's Lives from a Feminist Perspective. Taylor \& Francis Ltd, Basingstoke, pp. 72-93

Sløk-Andersen, B. (2018), The Becoming of Good Soldiers. An Ethnographic Exploration of Gender and Other Obstacles in the Military Borderland, PhD Dissertation, Faculty of Humanities, University of Copenhagen.

Sløk-Andersen, B. (2019), "The Butt of the Joke? Laughter and Potency in the Becoming of Good Soldiers", Cultural Analysis, Vol. 17 No. 1, pp. 25-56.

Smets, M., Burke, G., Jarzabkowski, P. and Spee, P. (2014), "Charting new territory for organizational ethnography Insights from a team-based video ethnography", Journal of Organizational Ethnography, Vol. 3 No. 1, pp. 10-26.

Spradley, J. P. (1980), Participant Observation, Wadsworth, Belmont, CA. 
Star, S. L. (1990), "Power, technology and the phenomenology of conventions: on being allergic to onions", The Sociological Review, Vol. 38, pp. 26-56.

Staunæs, D. and Kofoed, J. (2015), "Producing curious affects: visual methodology as an affecting and conflictual wunderkammer", International Journal of Qualitative Studies in Education, Vol. 28 No. 10, pp. 1229-1248.

Staunæs, D. (2016), "Notes on inventive methodologies and affirmative critiques of an affective edu-future", Research in Education, Vol. 96 No. 1, pp. 62-70.

Stewart, K. (2007), Ordinary Affects. Duke University Press, Durham and London.

Sørensen, B. R. and M. Weisdorf (2019), "Awkward moments in the anthropology of the military and the (im)possibility of critique", Ethnos, pp. 1-22.

Tracy, S. J. (2014), "Fieldwork horse-assery: Making the most of feeling humiliated, rebuffed, and offended during participant observation research", Management Communication Quarterly, Vol. 28 No 3, pp. 458465.

Van Maanen, J. (2011), "Ethnography as work: some rules of engagement", Journal of Management Studies, Vol. 48 No. 1, pp. 218-234.

Wacquant, L. (2006), Body \& Soul-Notebooks of an Apprentice Boxer. Oxford University Press, Oxford.

Warden, T. (2013), "Feet of clay: confronting emotional challenges in ethnographic experience", Journal of Organizational Ethnography, Vol. 2 No. 2, pp. 150-172.

White, D. (2017), “Affect: an introduction”, Cultural Anthropology, Vol. 32 No. 2, pp. 175-180.

\footnotetext{
${ }^{1}$ Military organization tends to be regarded and reiterated as out of the ordinary (for examples, see Felski, 2000). We have elsewhere contested such narratives of exceptionalism, arguing that they are part of a boundary work constituting and performing demarcations between inside/outside, military/civilian, masculine/feminine, and professional/unprofessional (Persson, 2011; Sløk-Andersen, 2018).

${ }^{2}$ On a similar note, Ashcraft (2017) has written a poetic and daring piece in which she through the affective aspects of academic labor - the anxiety and exhaustion - argues for the need and usefulness of an inhabited criticism. Effectively writing through and with affects, Ashcraft notes that "Through humor and personal warmth, I help to numb the skin as the neoliberal knife cuts, and people express gratitude." (ibid., p. 42)

${ }^{3}$ A few bold scholars have made attempts of writing difference/differently, not least Allison Pullen (see e.g. Pullen and Rhodes 2008, Pullen et al. 2017).
}

\section{Beate Sløk-Andersen}

Beate Sløk-Andersen, PhD, is a Postdoctoral Researcher at the Department of Organization, Copenhagen Business School, Denmark. Working on the intersection of gender studies and critical management studies, Sløk-Andersen's research focuses on processes of inclusion/exclusion, diversity, professional boundaries, and embodied processes of professional becoming. Coming from a background in Ethnology, Sløk-Andersen's research is typically founded on ethnographic fieldwork and pays particular attention to the subtle processes taking place in everyday life, e.g. bodily practices, norms, and routines.

\section{Alma Persson}


Alma Persson, $\mathrm{PhD}$, is a Senior Lecturer at the Unit for Gender Studies, Linköping University, Sweden. Her research interests include studies on gender, work and organizations; critical studies of men and masculinity; gender and the body in medical practice; and studies on gender and violence. Persson is currently involved in two research projects that focus on gender relations in military work; one focusing on the implementation of gender-neutral conscription and one on gender, diversity and security in the Nordic countries. Recent publications include "Conscripting women: Gender, soldiering, and military service in Sweden 1965-2018” in Women's History Review (2019). 